\title{
アカフジツボ幼生飼育条件に関する検討
}

\author{
吉村えり 奈 ${ }^{1)} \cdot$ 野方靖行 ${ }^{2} *$ ・坂口 勇 ${ }^{2)}$ \\ 1)(株)セレス、テ101-0052 東京都千代田区神田小川町1-6-1 \\ 2) (財) 電力中央研究所 環境科学研究所、 $=270-1194$ 千葉県我孫子市我孫子1646
}

\section{Experiments on rearing the barnacle Megabalanus rosa to the cyprid stage in the labo- ratory}

\author{
E. Yoshimura ${ }^{1)}$, Y. Nogata $^{2) *}$ and I. Sakaguchi ${ }^{2)}$ \\ 1) SERES Inc., 1-6-1, Ogawa-cho, Kanda, Chiyoda-ku, Tokyo 101-0052, Japan \\ ${ }^{2)}$ Environmental Science Research Laboratory, Central Research Institute of Electric Power Industry, 1646 Abiko, Abiko, \\ Chiba 270-1194, Japan
}

* corresponding author : Y.N., email : noga@criepi.denken.or.jp

(Received March 29, 2006 ; Accepted May 12, 2006)

\begin{abstract}
In order to develop a culture method for larvae of the major fouling barnacle Megabalanus rosa, we examined the effects of food concentration and larval density on the naupliar larval development and metamorphosis into the cyprid. When nauplius larvae were cultured with the diatoms Chaetoceros gracilis and/or Skeletonema costatum at different concentrations, metamorphosis rates to the cyprid increased with the diatom concentration up to $60 \times 10^{4}$ cells $/ \mathrm{ml}$. Naupliar survival rates and metamorphosis rates to the cyprid decreased with increasing larval density when nauplii were cultured at $20^{\circ} \mathrm{C}$ with $60 \times 10^{4}$ cells $/ \mathrm{ml}$ of the diatom mixture. From these results, it appears that larval density should be kept below 2 larvae $/ \mathrm{ml}$, and food concentration above $60 \times 10^{4}$ cells $/ \mathrm{ml}$, during mass culture of $M$. rosa larvae.
\end{abstract}

Key words: barnacle, Megabalanus rosa, larva, food concentration, cypris

フジツボ類は付着污損生物の代表的な種類であり、船 舶、魚網、ブイ、発電所冷却水路系など様々な海洋構造 物に付着、成長することで問題を引き起こすため、その 対策が強く望まれている(坂口 2003)。また、そのユニー クな生態や特殊なセメントタンパク質 (Okano et al., 1996）を有することからその付着機構に関する研究も盛 んに行われつつある。フジッボ類の付着機構や対策研究 を効率的に行うためには、付着期の幼生であるキプリス 幼生を大量に供給する必要があるが、採集によって海域 から年間を通してコンスタントにキプリス幼生を得るこ とができないため、フジツボ類の幼生飼育方法について
はこれまでにも数多く紹介されている（Moyse，1963； Hirano, 1963; 加戸 - 平野, 1979; Rittschof et al., 1984, 1992; Kon-ya and Miki, 1994; 北村, 1999; Mishra et al.,2001など)。それらの多くは、世界中に 分布し、潮間帯に生息するタテジマフジッボ (Amphibalanus amphitrite) であり、成体飼育、孵出方 法、幼生飼育などが確立していることから、本種が実験 材料として世界中で広く用いられている。

しかし，わが国においては実際に漁業，船舶，発電所 において問題となるフジツボの代表的な種類は大型種の アカフジツボ (Megabalanus rosa) である。また、アカ 
フジツボのキプリス幼生はタテジマフジツボなどのキプ リス幼生と比較して大きいため、セメント腺から分泌さ れるセメント物質に関する研究 (Okano et al., 1996) などにも用いやすいという利点がある。よってアカフジ ツボ幼生の飼育方法を確立することができれば、今後の 防污対策や付着入カニズム解明に関する研究に大きく寄 与することができると思われる。これまでにアカフジッ ボ幼生の飼育についてはKado and Hirano（1994）が個 体別飼育方法を、Okano et al. (1996) や松村ら (2002) が大量供給方法を報告しているが、飼育密度や飼育の際 の餌密度についての詳細な検討はなされていない。そこ で、本報告ではアカフジッボ幼生の飼育の際の飼育密度、 餌密度および餌の種類に関して、我々が行った実験の結 果を紹介する。

\section{材料と方法}

\section{成体アカフジッボと幼生の採集}

成体アカフジツボは越喜来湾（岩手県）および伊方 （愛媛県）で採集し実験室の水槽に収容した。成体アカ フジツボは 12 Lの天然海水（塩分約 $35 \%$ ）を用いて、各 水槽当たり $20 \sim 30$ 個体となるように収容し、 $20^{\circ} \mathrm{C} \pm 2{ }^{\circ} \mathrm{C}$ の恒温室で 6 回/週の頻度で朝にアルテミアを飽食量与 え、夕方に新しい海水との換水を行い飼育した。朝の段 階で幼生が孵化した際に、光を当てることで集まってき たノープリウス幼生を回収し、ろ過海水で洗浄して実験 に用いた。

\section{ノープリウス幼生飼育実験条件 \\ 1. 餌の種類と餌密度の検討}

ノープリウス幼生の餌量として、2 種類の珪藻、

Chaetoceros gracilis と Skeletonema costatumを培盖 し、餌密度とアカフジツボのノープリウス幼生の密度を 変えて実験した。

幼生は、 $500 \mathrm{ml}$ 容のビーカーを用い、 $0.2 \mu \mathrm{m}$ のフル ターでろ過した天然海水（塩分約 $35 \%$ ） 500m1中に収容 した。アカフジツボのノープリウス幼生の密度は、1 個 体 $/ \mathrm{m} 1$ と 2 個体 $/ \mathrm{m} 1$ の 2 段階とした。その際に、血球計算 盤で計数して求めた珪藻の細胞数にしたがって、下記の 設定密度となるように調整した。

設定 1 の実験では、 $10 \times 10^{4} \mathrm{ce} 11 \mathrm{~s} / \mathrm{ml} 、 20 \times 10^{4} \mathrm{ce} 11 \mathrm{~s}$ $/ \mathrm{m} 1 、 30 \times 10^{4} \mathrm{ce} 11 \mathrm{~s} / \mathrm{m} 1$ の 3 段階で実験を行い、飭の種 類としては，C.gracilis 単独およびC.gracilis と S. costatumを同じ細胞数になるように混合したものの 2 通りを設定した。設定 2 の実験では $30 \times 10^{4} \mathrm{cel} 1 \mathrm{~s} / \mathrm{ml}$ 、 $60 \times 10^{4} \mathrm{ce} 11 \mathrm{~s} / \mathrm{ml} 、 90 \times 10^{4} \mathrm{ce} 11 \mathrm{~s} / \mathrm{m} 1$ の 3 段階で、餌と しては, C. gracilis 単独, S. costatum 単独, C. gracilis と S. costatumを同じ細胞数となるように混 合したものの 3 種類を用いて実験した。実験はそれぞれ 3 回繰り返して行った。

すべての実験は $20^{\circ} \mathrm{Cに}$ 設定したインキュベーター内で 行い、24時間連続照明で各ビーカーの照度が1500〜2500 1x程度となるようにし、エアレーションはガラス管を用 いて170〜200 ml/minの量で連続通気を行った。毎日 1
回新しい餌の入った飼育ビーカーと交換して 8 日間飼育 し，キプリス幼生が出現し始めた飼育 8 日目からは換水 せずに 2 日間培養した。早い時期に変態したキプリス幼 生がビーカーに付着してしまう前の飼育10日目に目合い $220 \mu \mathrm{m}$ のプランクトンネットを用いて幼生を回収し，50 $\mathrm{ml}$ 容プラスチック製試験管 $50 \mathrm{ml}$ に濃縮した。設定 1 の実 験では、回収した幼生をすべて実体顕微鏡下で観察・計 数した。設定 2 の実験では、 $50 \mathrm{~m} 1$ に濃縮した海水を十分

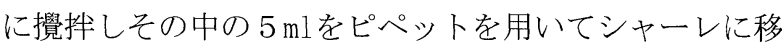
し，実体顕微鏡下でノープリウスとキプリスの個体数を 計数した。この操作を 3 回繰り返し，キプリスに変態し た割合の平均值からキプリス幼生への変態率を算出した。

\section{2. 飼育密度の検討}

アカフジツボのノープリウス幼生の密度は、1 個体、 2 個体、3 個体、 4 個体および 5 個体 $/ \mathrm{m} 105$ 段階とし た。幼生は、 $500 \mathrm{ml}$ 容のビーカーに $0.2 \mu \mathrm{m}$ のフルター でろ過した天然海水（約35\%o）500m1中に収容し、各 2 連（Exp1，Exp2）で実験を行った。餌密度は $60 \times 10^{4} \mathrm{ce} 1$ 1s/m1 としてC. gracilis と S. costatumの1:1に混合した もの（それぞれ $30 \times 10^{4} \mathrm{ce} 11 \mathrm{~s} / \mathrm{m} 1 ）$ を与えて飼育を行っ た。他の条件は前述の実験と同様とした。

飼育 10 日後に目合い $220 \mu \mathrm{m}$ のプランクトンネットを用 いて回収し，50m1容プラスチック製試験管 $50 \mathrm{~m} 1$ に濃縮し、 回収した幼生をすべて実体顕微鏡下で観察・計数した。 計数時にキプリス幼生、6 令後期幼生、その他と区別し てカウントし、飼育開始時の設定幼生数に対する生残率 および生残個体数に対するキプリス幼生への変態率を算 出した。

\section{結果}

\section{1. 餌の種類と餌密度}

設定 1 で飼育した場合のキプリス幼生への変態率を Fig. 1.とFig. 2 に示す。C.gracilis 単独、C.gracilis と S. costatum混合のどちらの慨条件においても、慨密 度の上昇に伴いキプリス幼生への生残率、変態率共に高 くなる傾向が見られた。生残率が最も低かったのは飼育 密度 2 個体 $/ \mathrm{m} 1 、$. gracilis 単独の餌密度 $10 \times 10^{4} \mathrm{cells}$

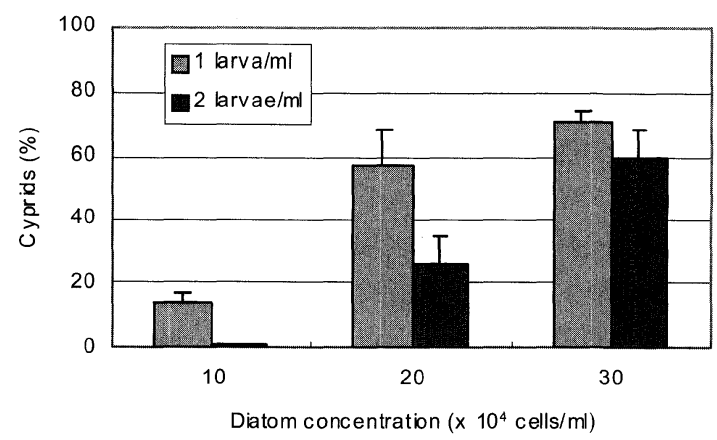

Fig. 1 Metamorphosis rate into cyprids of Megabalanus rosa nauplius larvae cultured at different concentrations of nauplii and the Chaetoceros gracilis. Error bars indicate SD. 


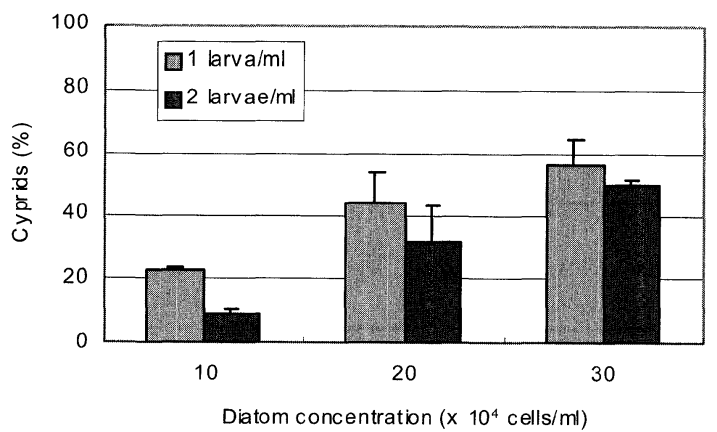

Fig. 2 Metamorphosis rate into cyprids of Megabalanus rosa nauplius larvae cultured at different concentrations of nauplii and the Chaetoceros gracilis and Skeletonema costatum mixture. Error bars indicate SD.

$/ \mathrm{m} 1$ の条件で、3 回の平均は $20.3 \%$ あった。生残率が もっとも高かったのは飼育密度 1 個体 $/ \mathrm{m} 1 、$ C. gracilis とS. costatum混合の餌密度 $30 \times 10^{4} \mathrm{ce} 11 \mathrm{~s} / \mathrm{m} 1$ の条件であ り、3 回の平均は $49.4 \%$ であった。飼育密度が低い方が 同じ䬺条件下では生残率が高くなり、同じ慨密度におい ては C. gracilis 単独よりもC. gracilis と S. costatum 混合のほうで生残率が高くなった。生残個体中のキプリ ス幼生一の変態は飼育密度 2 個体 $/ \mathrm{m} 1$ 、餌密度 $10 \times 10^{4}$ cells/m10条件では、ほとんど観察されなかった。また、

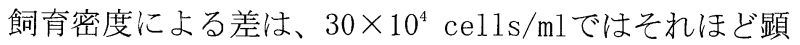
著ではないものの、1 個体 $/ \mathrm{m} 1$ の飼育密度のほうがキプ リスへの変態率が高くなった。餌種類による差は、 $10 \times$ $10^{4} \mathrm{ce} 11 \mathrm{~s} / \mathrm{m} 1$ 以外の餌密度では、C. gracilis 単独による 飼育の方が生残個体中の変態率としては高くなったが、 生残率が低いために得られたキプリスの総数としては C. gracilis $と$ S. costatum混合のほうが多くなった。

設定 2 で飼育した結果をFig. 3 〜 に示した。何れの 餌条件においても、 $60 \times 10^{4} \mathrm{ce} 11 \mathrm{~s} / \mathrm{ml}$ 以上の餌密度でキ プリス幼生への変態率が $80 \%$ 程度と高く推移し、飼育密 度による差もほとんど見られなかった。S. costatum 単 独飼育の場合には、 $30 \times 10^{4} \mathrm{ce} 11 \mathrm{~s} / \mathrm{ml}$ の 2 個体 $/ \mathrm{ml}$ 飼育 では他の条件と比べてキプリスへの変態率が低下した。

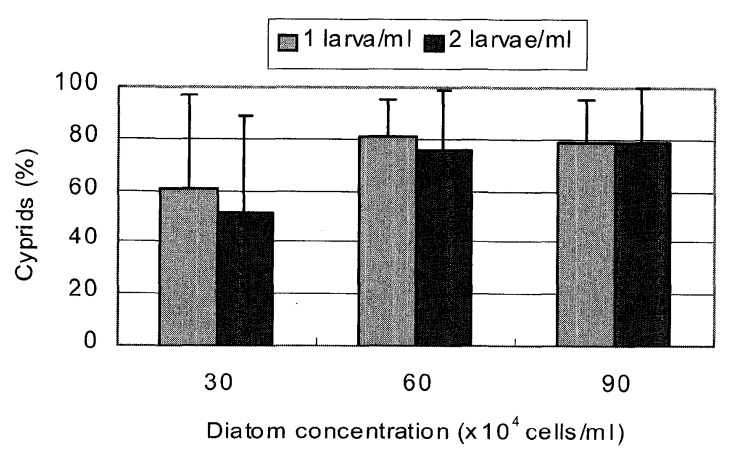

Fig. 3 Metamorphosis rate into cyprids of Megabalanus rosa nauplius larvae cultured at different concentrations of nauplii and the Chaetoceros gracilis. Error bars indicate SD.

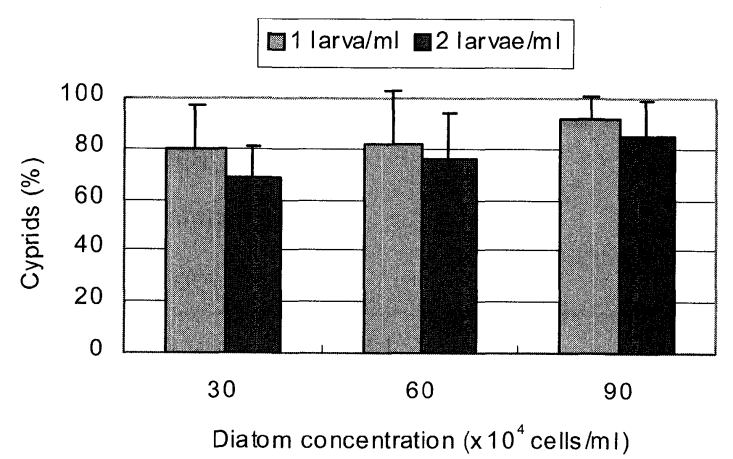

Fig. 4 Metamorphosis rate into cyprids of Megabalanus rosa nauplius larvae cultured at different concentrations of nauplii and the Chaetoceros gracilis and Skeletonema costatum mixture. Error bars indicate SD.

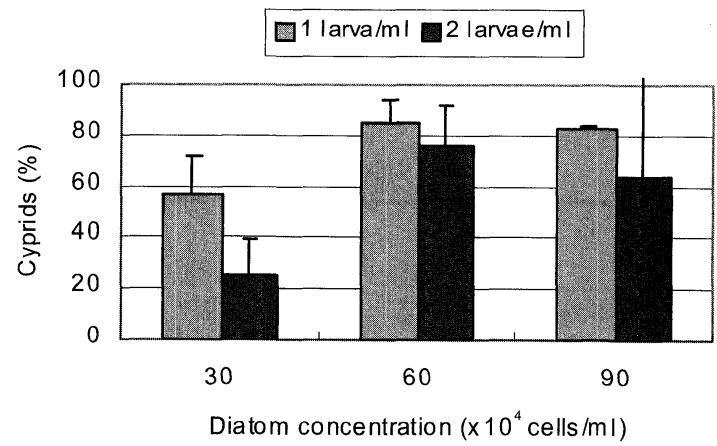

Fig. 5 Metamorphosis rate into cyprids of Megabalanus rosa nauplius larvae cultured at different concentrations of nauplii and the Skeletonema costatum. Error bars indicate SD.

\section{2. 飼育密度}

Fig. 6 に実験終了時に計数した幼生数から算出した生 残率を、Table 1に生残個体中のキプリス幼生への変態 率を示した。Fig. 6 とTable. 1 に示したように、1 個体 $/ \mathrm{ml}$ や 2 個体 $/ \mathrm{m} 1$ で飼育した場合には、キプリス幼生へ の変態率が $90 \%$ 前後と非常に高率であったのに対して、 飼育密度が高くなるにつれて、生残率とキプリス幼生へ の変態率の低下が認められた。また、 1 個体 $/ \mathrm{m} 1$ や 2 個

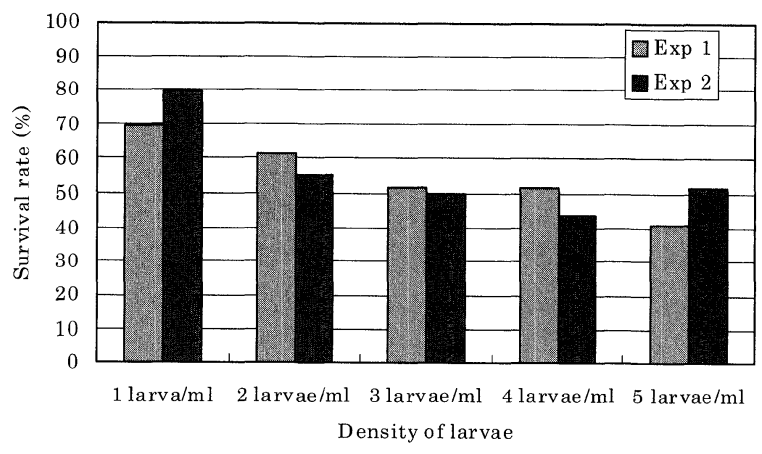

Fig. 6 Survival rate after 10 days of Megabalanus rosa nauplius and cypris larvae cultured at different larval densities with $60 \times 10^{4}$ cells $/ \mathrm{ml}$ of food (Chaetoceros gracilis and Skeletonema costatum mixture). 
Table 1. Metamorphosis rate into cyprids and the number of larvae in the nauplius stages after 10 days of Megabalanus rosa cultured at different larval densities with $60 \times 10^{4}$ cells $/ \mathrm{ml}$ of food (Chaetoceros gracilis and Skeletonema costatum mixture).

\begin{tabular}{|c|c|c|c|c|c|c|}
\hline \multirow[b]{2}{*}{ Larval density } & & \multirow{2}{*}{$\begin{array}{c}\text { Rate of } \\
\text { metamorphosis to } \\
\text { cyprids (\%) }\end{array}$} & \multicolumn{4}{|c|}{ Number of larvae } \\
\hline & & & Total & Cyprids & Late nauplius VI & $\begin{array}{c}\text { Other naupliar } \\
\text { stages }\end{array}$ \\
\hline \multirow{2}{*}{1 larva/ml } & Exp1 & 94 & 347 & 325 & 13 & 9 \\
\hline & Exp2 & 93 & 398 & 369 & 22 & 7 \\
\hline \multirow{2}{*}{2 larvae/ml } & Exp1 & 90 & 614 & 552 & 34 & 28 \\
\hline & Exp2 & 87 & 556 & 484 & 45 & 27 \\
\hline \multirow{2}{*}{3 larvae $/ \mathrm{ml}$} & Exp1 & 78 & 774 & 605 & 95 & 74 \\
\hline & Exp2 & 77 & 756 & 581 & 109 & 66 \\
\hline \multirow{2}{*}{4 larvae $/ \mathrm{ml}$} & Exp1 & 61 & 1029 & 624 & 248 & 157 \\
\hline & Exp2 & 52 & 876 & 459 & 232 & 185 \\
\hline \multirow{2}{*}{5 larvae $/ \mathrm{ml}$} & Exp1 & 30 & 1021 & 307 & 427 & 287 \\
\hline & Exp2 & 24 & 1288 & 308 & 546 & 434 \\
\hline
\end{tabular}

体/m1で飼育した場合には、キプリス幼生は飼育 8 日目 あたりで多く出現したが、飼育密度が高くなるにつれて、 幼生のステージのばらつきが大きくなることが認められ た。

\section{考 察}

フジツボのキプリス幼生を実験に用いる際には、なる だけ多くの個体が同調して得られるほうが望ましいと考 えられる。今回の実験の結果、アカフジッボのキプリス 幼生を安定して大量に供給するためには、 $20^{\circ} \mathrm{C}$ の飼育条 件下であれば、餌密度は $60 \times 10^{4} \mathrm{ce} 1 \mathrm{ls} / \mathrm{m} 1$ 以上、飼育個 体密度は 2 個体 $/ \mathrm{ml}$ 以下が望ましいことが示唆された。 キプリス幼生への変態率やキプリス幼生になるタイミン グについては餌の密度に依存していると考えられるため、 今回設定した餌密度以上で供給すれば、これよりも高密 度での飼育も可能となることも考えられる。しかし、タ テジマフジッボの場合でも、キプリス幼生への移行が順 調となる飼育密度はそれほど高くはなく、2 個体/m1以 下（北村、1999）である。よって、その後の付着実験な どに同質のキプリス幼生を供給する点から考えた場合に は、飼育密度は松村ら（2002）と同じように 1 個体 $/ \mathrm{ml}$ 以下程度がよいと思われる。飭の珪藻に関しては、餌密 度を高く設定することでアカフジツボの幼生もタテジマ フジッボなどと同じようにC.gracilisや S. costatumを 用いた大量飼育が可能であった。サンカクフジッボ Balanus trigonusの幼生飼育 (Mishra et. al., 2001) においては、 $50 \times 10^{4} \mathrm{ce} 11 \mathrm{~s} / \mathrm{m} 1$ がキプリス幼生への変態 率、生残率の面から最適であることからも、飼育するフ ジッボの種類によって最適な慨密度は異なると考えられ る。今回の実験の結果からアカフジツボについては、珪 藻を $60 \times 10^{4} \mathrm{ce} 11 \mathrm{~s} / \mathrm{m} 1$ 程度の餌密度で与えることで変態
時期を同調させたキプリス幼生を大量に獲得することが できると考えられる。このことは、加戸・瀬川（1996） がアカフジツボ幼生を用いて $40 \times 10^{4} \mathrm{ce} 11 \mathrm{~s} / \mathrm{ml}$ と $10 \times 10^{4}$ cel1s $/ \mathrm{m} 1$ の餌密度でC. calcitrans を与えて比較実験を 行っているが、慨密度が高いほうがキプリス幼生までの 所要日数が短く、同調性も高くなるという結果とも一致 している。

今回の実験で得られたキプリス幼生を用いて、ポリス チレンシャーレを用いた付着実験を行ったが、同じ実験 条件での繰り返し閒のばらつきが非常に大きくなった。 アカフジツボの場合、 $20^{\circ} \mathrm{C}$ 条件下ではノープリウス幼 生から変態したキプリス幼生は付着能を有するまでに数 日必要であると考えられ、変態直後〜 1 日令のキプリス 幼生はほとんど探索行動などを行わない。付着実験の大 きなばらつきがそれらの成熟条件によるものなのか、他 の因子によるものなのかは今回の実験で明らかにするこ とはできなかった。付着機構の解明や付着実験のために は、付着率も安定していることが望ましいため、今後は 安定した付着率を示すようなキプリス幼生回収方法、加 齢方法あるいはアッセイ方法の検討を行っていく必要が ある。

\section{謝 辞}

本実験を行うにあたり、多大な協力と助言をいただい た北里大学水産学部助教授加戸隆介博士に深く感謝の意 を表します。

\section{引用文献}

Hirano, R. (1963). Mass rearing of barnacle larvae. Bull. Mar. Biol. Sta. Asamushi, Tohoku Univ., 11, 77-80.

加戸隆介、瀬川真一郎 (1996). アカフジツボ幼生の飼育およ 
び付着について. 第 3 回付着生物研究会・研究集会発表要 旨

加戸隆介、平野礼次郎 (1979). 付着生物浮遊期幼生の飼育法. 付着生物研究, 1 (1), 11-19.

Kado, R. and R. Hirano (1994). Larval development of two Japanese megabalanine barnacles, Megabalanus volcano (Pilsbry) and Megabalanus rosa (Pilsbry) (Cirripedia, Balanidae), reared in the laboratory. J. Exp. Mar. Biol. Ecol., 175, 17-41.

北村 等 (1999).タテジマフジツボ幼生の飼育法およびキプリ 幼生を用いた循環流水式の付着試験法. Sessile Organisms, 15 (2), 15-21.

Kon-ya, K. and W. Miki (1994). All-seasonal assay for antifouling substances using reared barnacle larvae. J. Mar. Biotechnol., 1, 193-195.

松村清隆、山下桂司、神谷享子、岡田佳子、柳川敏治、岡洋祐、 川端豊喜 (2002).タテジマフジッボおよびアカフジッボ キプリス幼生の着生における着生誘起タンパク質と付着基 盤性状の重要性. Sessile Organisms, 19 (2), 93-99.

Mishra, J. K., H. Kitamura and K. Tomoda (2001). Laboratory culture of Balanus trigonus larvae by the method of $B$. amphitrite for establishing a multi-species settlement assay. Sessile Organisms, 18 (1), 1-6.
Moyse, J. (1963). A comparison of the value of various flagellates and diatoms as food for barnacle larvae. J. Cons. Perm. Int. Explor. Mer, 28, 175-187.

Okano, K., K. Shimizu, C. G. Satuito and N. Fusetani (1996). Visualization of cement exocytosis in the cypris cement gland of the barnacle Megabalanus rosa. J. Exp. Biol., 199, 2131-2137.

Rittschof, D., E. S. Branscomb and J. D. Costlow (1984). Settlement and behavior in relation to flow and surface in larval barnacle, Balanus amphitrite Darwin. J. Exp. Mar. Biol. Ecol., 82, 131-146.

Rittschof, D., A. S. Clare, D. J. Gerhart, A. V. Sister and J. Bonaventura (1992). Barnacle in vitro assays for biologically active substances: toxicity and settlement inhibition assays using mass cultured Balanus amphitrite amphitrite Darwin. Biofouling, 6, 115-122.

坂口勇 (2003). 発電所の污損生物対策技術の展望. Sessile Organisms, 20 (1), 15-19. 